\title{
Determination of Benzo(a)pyrene Levels in Smoked Clarias gariepinus and Heterotis niloticus in Hadejia Jigawa State and Geriyo Adamawa State
}

Sogbesan Olukayode Amos ${ }^{1 *}$ and Usman Muhammed Sambo ${ }^{2}$

${ }^{1}$ Department of Fisheries, Modibbo Adama University of Technology, Yola, Admawa State, Nigeria

${ }^{2}$ Department of Fisheries, Binyaminu Usman Polytechnic, Hadejia, Jigawa State, Nigeria

*Corresponding Author: Sogbesan Olukayode Amos, Department of Fisheries, Modibbo Adama University of Technology, Yola, Admawa State, Nigeria, Tel: +2348161518198; E-mail: sokayfish@ gmail.com

Received: 01 August 2017; Accepted: 02 September 2017; Published: 14 September 2017

\begin{abstract}
This study determined the levels of benzo(a)pyrene in smoked Clarias gariepinus and Heterotis niloticus. Questionnaire was administered to fish processors at the Hadejia and Geriyo fish processing units, the result obtained from analysis of the questionnaire shows that majority of the fish processors in Hadejia are using Neem tree (Azadrachta indica) wood and rectangular smoking kiln while in Geriyo majority of the fish processors are using Chew stick tree (Anageisus leiocarpus) wood and Drum smoking kiln. Sample of fish processed were collected and also fresh fish were processed using the type of firewood commonly used by the fish processors. The Fresh fish samples were used as control. All the smoked and fresh fish samples were subjected to laboratory analysis to determine the level of benzo(a)pyrene. Data generated were subjected to One-way ANOVA. The results obtained show that highest Benzo(a)pyrene recorded in this study is from C. gariepinus smoked in Hadejia market having $14.91 \mu \mathrm{g} / \mathrm{kg}$ followed by the same species smoked in Geriyo with $13.69 \mu \mathrm{g} / \mathrm{kg}$ of BaP while the lowest was recorded in H. niloticus smoked with chew stick with $7.61 \mu \mathrm{g} / \mathrm{kg}$. There is significant difference $(\mathrm{p}<0.05)$ in the level of $\mathrm{BaP}$ in smoked Clarias gariepinusand Heterotis niloticus across the samples. All the smoked fish samples examined in this study were found to be higher than the acceptable limit $(5 \mu \mathrm{g} / \mathrm{kg})$ specified by the European Union commission, but when they were evaluated according to FAO/WHO limits $(10 \mu \mathrm{g} / \mathrm{kg})$. Four samples (40\%) analyzed were over
\end{abstract}


the acceptable limit. This result is recommending the smoking of fish using Chew stick wood for reduction in the BaP levels in the food product.

Keywords: Benzo(a)pyrene; Smoked fish; Woods, Socio-economic; Livelihood

\section{Introduction}

Fish processing through smoking has gained a lot of ground in the field of food processing and it is commonly practiced by small, medium and large scale processing industries. The smoke which is produced either from wood or coal fuel contains a member of polycyclic aromatic hydrocarbons (PAHs) called Benzo[a]pyrene (BaP) which is a large group of organic compounds with sufficient toxicological evidence for mutagenic and carcinogenic properties $[1-3]$.

In Nigeria, smoked fish is a common source of protein in the diets of many households [4]. In Nigeria, consumers are less aware of the presence of these residues in food products. There is no published data on the residual levels of benzo[a]pyrene on food products and furthermore no safety assessment of food items is done in Nigeria with regard to benzo[a]pyrene to ensure consumer protection The maximum acceptable level for benzo[ $\alpha]$ pyrene for the European Union market in smoked fish is $5 \mu \mathrm{g} / \mathrm{kg}$, [5] while for WHO it is $10 \mu \mathrm{g} / \mathrm{kg}$. Safety of food is a growing concern worldwide and PAHs residues if present in food above the maximum residual limit (MRL) pose a serious threat to the public health. Determination of the residual levels of benzo[A]pyrene in smoked fish will help to develop strategies that reduce the actual and potential risk to public health and establish systems for controls and interventions to ensure compliance with the recommended levels of benzo[A]pyrene in smoked fish.

\section{Materials and Methods}

This research was conducted at two different locations, which are Hadejia in Jigawa state and Geriyo in Adamawa state. A structured questionnaire was administered using a Focus Group Approach to fisher folks in the two locations that are involved in fish processing through smoking. Types of Wood reported through the questionnaire as commonly used were collected. Freshly landed Clarias gariepinus and Heterotis niloticus were bought from fishers.The sourced fresh fish samples were degutted, washed and allowed to drain. Initial weight of the sample was measured prior to smoking, the sample were then placed on smoking kiln.Weight of the fish samples were taken at two (2) hours intervals until constant weight is attained.

All the samples (fresh and smoked) were subjected to laboratory analysis to determine the levels of Benzo(a)pyrene, the fresh fish samples was served as control. High performance liquid chromatography (HPLC) using fluorescence detection was used in determination $\mathrm{BaP}$ as described by Muyela et al. [6]. The data collected from the laboratory for both Benzo(a)pyrene levels in smoked and fresh fish samples were subjected to Analysis of variance(ANOV A). The least significance difference (LSD) procedure was used to test for the difference between the treatments values with significance being defined at $\mathrm{p} \leq 0.05$. 


\section{Results and Discussions}

The results of this study indicated that $100 \%$ of the respondents in Hadejia are within 21-35 years of age while in Geriyo $55.55 \%$ are above 45 years of age, the study also revealed that $100 \%$ of the respondents in Hadejia are male while in Geriyo $61.11 \%$ are male and remaining $38.89 \%$ are female. In terms of educational status, majority of the respondents in Hadejia have secondary and tertiary education with $38.46 \%$ and $34.61 \%$ while in Geriyo $50.00 \%$ had quranic education. In terms of marital status, $61.58 \%$ of the respondents in Hadejia and in Geriyo $88.88 \%$ are married. In terms of Household size, $61.58 \%$ of the respondents in Hadejia had family size of 1-3 persons while in Geriyo 33.33\% had 7-10 and 33.33\% had above 10 persons in their household. In terms of years of experience, $69.23 \%$ of the respondents in Hadejia have 6-10years experience while in Geriyo $55.55 \%$ has above 20 years experience. In terms of means of livelihood, in Hadejia, 30.76\% of the respondents depend on fish processing only, $38.46 \%$ depend on fish processing and fish trade and $30.76 \%$ depend on fish processing and other business while in Geriyo 38.88\% depend on fish processing only, 33.33\% depend on fish processing and fish trade and remaining $27.78 \%$ depend on fish processing and other business as shown in Table 1. Figure 1 shows the different livelihood of the fisher folks.

\begin{tabular}{|c|c|c|c|c|}
\hline \multirow[t]{2}{*}{ Variables } & \multicolumn{2}{|c|}{ Frequency } & \multicolumn{2}{|c|}{ Percentages (\%) } \\
\hline & Hadejia & Geriyo & Hadejia & Geriyo \\
\hline \multicolumn{5}{|l|}{ Age } \\
\hline $15-20$ & 0 & 0 & 0.00 & 0.00 \\
\hline $21-35$ & 26 & 6 & 100 & 33.33 \\
\hline $36-45$ & 0 & 2 & 0.00 & 11.11 \\
\hline Above 45 & 0 & 10 & 0.00 & 55.55 \\
\hline Total & 26 & 18 & 100 & 100 \\
\hline \multicolumn{5}{|l|}{ Gender } \\
\hline Male & 26 & 11 & 100 & 61.11 \\
\hline Female & 0 & 6 & 0.00 & 38.89 \\
\hline Total & 26 & 18 & 100 & 100 \\
\hline \multicolumn{5}{|c|}{ Educational status } \\
\hline Not educated & 0 & 3 & 0.00 & 16.66 \\
\hline Qur'anic & 4 & 9 & 15.38 & 50.00 \\
\hline Primary & 3 & 3 & 11.58 & 16.66 \\
\hline Secondary & 10 & 3 & 38.46 & 16.66 \\
\hline Tertiary & 9 & 0 & 34.61 & 0.00 \\
\hline Total & 26 & 18 & 100 & 100 \\
\hline \multicolumn{5}{|l|}{ Marital status } \\
\hline Married & 10 & 16 & 38.46 & 88.88 \\
\hline Single & 16 & 2 & 61.58 & 11.12 \\
\hline Total & 26 & 18 & 100 & 100 \\
\hline
\end{tabular}




\begin{tabular}{|c|c|c|c|c|}
\hline \multicolumn{5}{|l|}{ Household size } \\
\hline $1-3$ & 16 & 3 & 61.58 & 16.66 \\
\hline $4-6$ & 10 & 3 & 38.46 & 16.66 \\
\hline $7-10$ & 0 & 6 & 0.00 & 33.33 \\
\hline Above 10 & 0 & 6 & 0.00 & 33.33 \\
\hline Total & 26 & 18 & 100 & 100 \\
\hline \multicolumn{5}{|l|}{ Years of experience } \\
\hline $1-5$ & 1 & 2 & 3.84 & 11.11 \\
\hline $6-10$ & 18 & 2 & 69.23 & 11.11 \\
\hline $11-15$ & 7 & 1 & 26.92 & 5.55 \\
\hline $16-20$ & 0 & 3 & 0.00 & 16.66 \\
\hline Above 20 & 0 & 10 & 0.00 & 55.55 \\
\hline Total & 26 & 18 & 100 & 100 \\
\hline \multicolumn{5}{|l|}{ Means of livelihood } \\
\hline Fish processing only & 8 & 7 & 30.76 & 38.88 \\
\hline Fish processing and fish marketing & 10 & 6 & 38.46 & 33.33 \\
\hline Processing and other business & 8 & 5 & 30.76 & 27.78 \\
\hline Total & 26 & 18 & 100 & 100 \\
\hline
\end{tabular}

Table 1: Socio-economic status of fish processors sampled for Hadejia and Geriyo.

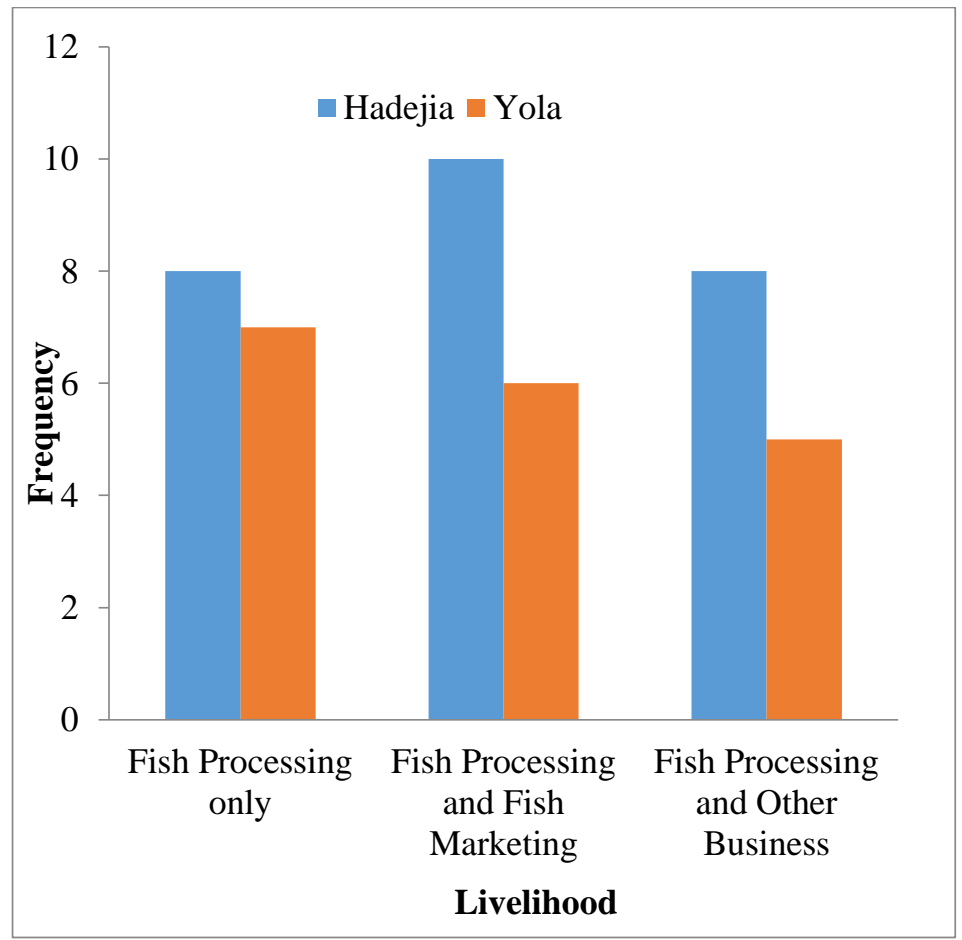

Figure 1: Variation in livelihood of the fisherfolks from Hadejia and Geriyo. 


\begin{tabular}{|c|c|c|c|c|}
\hline \multirow[b]{2}{*}{ Research question } & \multicolumn{2}{|c|}{ Frequency } & \multicolumn{2}{|c|}{ Percentage (\%) } \\
\hline & Hadejia & Geriyo & Hadejia & Geriyo \\
\hline \multicolumn{5}{|l|}{ Type of fuel used } \\
\hline Firewood & 26 & 18 & 100 & 100 \\
\hline Charcoal & 0 & 0 & 0 & 0 \\
\hline Total & 26 & 18 & 100 & 100 \\
\hline \multicolumn{5}{|l|}{ If firewood what type } \\
\hline Neem only & 8 & 1 & 30.76 & 5.55 \\
\hline Gum Arabic only & 3 & 0 & 11.53 & 0 \\
\hline Ebony tree only & 1 & 0 & 3.84 & 0 \\
\hline Chew stick only & 0 & 7 & 0 & 38.88 \\
\hline Neem \& Gum Arabic & 7 & 0 & 26.92 & 0 \\
\hline Neem and Ebony & 6 & 0 & 23.07 & 0 \\
\hline Neem \& chew stick & 0 & 6 & 0 & 33.33 \\
\hline Gum Arabic and ebony & 0 & 0 & 0 & 0 \\
\hline Gum Arabic \& chew stick & 0 & 0 & 0 & 0 \\
\hline Ebony and chew stick & 0 & 0 & 0 & 0 \\
\hline Any type of the wood above available & $\mathbf{0}$ & 6 & $\mathbf{0}$ & 33.33 \\
\hline Total & 26 & 18 & 100 & 100 \\
\hline \multicolumn{5}{|l|}{ Why choice of the firewood } \\
\hline Availability & 4 & 2 & 15.38 & 11.11 \\
\hline Aroma & 0 & 4 & 0 & 22.22 \\
\hline Economical & 12 & 2 & 46.15 & 11.11 \\
\hline Smoked fish colour & 10 & 10 & 38.46 & 55.55 \\
\hline Total & 26 & 18 & 100 & 100 \\
\hline \multicolumn{5}{|c|}{ Is the wood of choice commonest in the area } \\
\hline Yes & 26 & 18 & 100 & 100 \\
\hline $\mathrm{NO}$ & 0 & 0 & 0 & 0 \\
\hline Total & 26 & 18 & 100 & 100 \\
\hline
\end{tabular}

Table 2: Type of firewood used by fish processors in Hadejia and Geriyo.

The result obtained shows that $100 \%$ of the respondents in Hadejia and Geriyo used firewood as fuel source in processing their fish is shown on Table 2. In terms of type of firewood used, in Hadejia $30.76 \%$ of the respondents used firewood from Neem tree only, $11.53 \%$ uses firewood from Gum Arabic tree only, 3.84\% uses firewood from Ebony tree only $26.92 \%$ uses firewood from Neem \& Gum Arabic tree while in Geriyo, 38.88\% of the respondents uses firewood from chew stick tree only, 33.33\% uses firewood from chew stick and Neem tree, 33.33\% uses firewood from either Neem, Ebony, Chew stick and Gum Arabic tree and only 5.55\% uses firewood from Neem tree 
only as shown in the Table 2 . In terms of choice of firewood, in Hadejia $46.15 \%$ of the respondents choices fire wood for economical reason, $38.46 \%$ for smoked fish.

Colour and $\mathbf{1 5 . 3 8 \%}$ for availability while in Geriyo $55.55 \%$ of the respondents choices firewood for smoked fish colour, $22.22 \%$ choices for aroma, $11.11 \%$ choices for availability and remaining $11.11 \%$ choices for economical reason as shown in Table 2.

\begin{tabular}{|l|l|l|l|l|l|l|}
\hline Fish species & $\begin{array}{l}\text { Fresh } \\
(\boldsymbol{\mu g} / \mathbf{k g})\end{array}$ & $\begin{array}{l}\text { Smoked } \\
\text { Hadejia } \\
(\boldsymbol{\mu g} / \mathbf{k g})\end{array}$ & $\begin{array}{l}\text { Smoked } \\
\text { Geriyo } \\
(\boldsymbol{\mu g} / \mathbf{k g})\end{array}$ & $\begin{array}{l}\text { Smoked } \\
\text { with Neem } \\
(\boldsymbol{\mu g} / \mathbf{k g})\end{array}$ & $\begin{array}{l}\text { Smoked } \\
\text { chew } \\
\text { Stick }(\boldsymbol{\mu g} / \mathbf{k g})\end{array}$ & $\begin{array}{l}\text { Recommended } \\
(\boldsymbol{\mu g} / \mathbf{k g})\end{array}$ \\
\hline Clarias gariepinus & 0.00 & $14.91^{\mathrm{a}}$ & $13.69^{\mathrm{ab}}$ & $12.74^{\mathrm{b}}$ & $9.82^{\mathrm{c}}$ & 10.00 \\
\hline Heterotis niloticus & 0.00 & $9.93^{\mathrm{ab}}$ & $11.51^{\mathrm{a}}$ & $8.46^{\mathrm{bc}}$ & $7.61^{\mathrm{c}}$ & 10.0 \\
\hline
\end{tabular}

Data on the same row with difference superscripts are significantly difference $(\mathrm{p}<0.05)$.

Table 3: Benzo(a)pyrene concentration in the samples.

The highest Benzo(a)pyrene recorded in this study is from C. gariepinus smoked in Hadejia market having 14.91 $\mu \mathrm{g} / \mathrm{kg}$ followed by the same species smoked in Geriyo with $13.69 \mu \mathrm{g} / \mathrm{kg}$ of BaP while the lowest was recorded in $H$. niloticus smoked with chew stick (Table 3). There was significant difference $(\mathrm{p}<0.05)$ in the level of BaP in smoked Clarias gariepinus and Heterotis niloticus across thesamples. The concentration of BaP in the fish samples varied with smoke source. The level of BaP recorded may be attributed to the intensities of the smoke and heat generated by the smoking material which determine the drying duration of the fishes and hence, their contact time with smoke. This findings also corroborates the report of similar study by Silver et al. [7] that smoked fishes processes by firewood has highest level of $\mathrm{BaP}$ in smoked fishes. Various studies have reported the levels of BaP in smoked fish, according to Stolyhwo and Sikorski [8], most of the PAHs in smoked foods come from the wood smoke and that smoked fish contain much more PAH than the raw material from about 0.05 to about $60 \mu \mathrm{g}$ of $\mathrm{BaP} / \mathrm{kg}$ of $\mathrm{product}$, this is dependent on the properties of the fish, method and parameters of smoking, composition of the smoke and exposure of the edible parts to the smoke. This was satisfactorily established in this study.

The levels of $\mathrm{BaP}$ in smoked fish determined in this study indicate that the BaP levels are generally above the maximum residue limit recommended by different international and European regulations and hence pose a health risk to consumers.

\section{References}

1. Moret S, Purcaro G, Conte IS. Polycyclic aromatic hydrocarbon in vegetable oils from canned foods European Journal of Lipid science and Technology 107 (2005): 488-496.

2. Yusty MA, Davina CJ. Supercritical fluid extraction and high performance liquid chromotographyfluorescence detection method for polycyclic aromatic hydrocarbons investigation in Vegetable oil. Food control 16 (2005): 59-64. 
3. Ramalhosa MJ, Paula P, Simone M, et al. Analysis of polycyclic Aromatic hydrocarbons in fish: Evaluation of a quick, easy, cheap, effective, rugged and safe Extraction method. Journal of separation science 32 (2009): 3529-3538.

4. Bille G, Shemkai RH. Process development, nutrition and sensory characteristics Of spiced- somked and sun-dried dagaa (Rastrineobolaargentea) from lake victoria, Tanzania. African Journal of food, Agriculture. Nutrition and Development 6 (2006): 2-3.

5. European Commission. Commision recommendation on the further investigation in to the levels Of polycyclic aromatic hydrocarbons in certain foods. Notified under document number C (2005/256) (2005/108/EC). Official Journal of the European Union 314 (2005): 4-9.

6. Muyela B, Shitandi A, Ngure R. Determination of Benzo(a)pyrene levels in smoked and Oil fried Latesniloticus. International food research Journal 19 (2012): 1595-1600.

7. Silver BO, Adetunde OT, Oluseyi TO, et al. Effect of the method of smoking on the levels of Polycyclic aromatic hydrocarbons (PAHs) in some locally Consumed fishes in Nigeria. African journal of food science 57 (2011): 384-391.

8. Stolyhwo A, Sikorski ZE. Polycyclic aromatic hydrocarbons in smoked fish: A critical review. Food Chemistry 91 (2005): 303-311.

(C) 1 This article is an open access article distributed under the terms and conditions of the Creative 